\title{
Demineralization of Sargassum spp. macroalgae biomass: selective hydrothermal liquefaction process for bio-oil production
}

\author{
Liz M. Díaz-Vázquez ${ }^{1}{ }^{*}$, Arnulfo Rojas-Pérez ${ }^{1}$, Mariela Fuentes-Caraballo ${ }^{1}$, Isis V. Robles ${ }^{1}$, Umakanta Jena ${ }^{2}$ \\ and K. C. Das ${ }^{3}$
}

1 Department of Chemistry, University of Puerto Rico Río Piedras Campus, San Juan, PR, USA

2 Bioenergy Laboratory, Desert Research Institute, Reno, NV, USA

${ }^{3}$ College of Engineering, University of Georgia, Athens, GA, USA

\author{
Edited by: \\ S. Kent Hoekman, Desert Research \\ Institute, USA \\ Reviewed by: \\ Lixin Cheng, Aarhus University, \\ Denmark \\ Hao Liu, South China University of \\ Technology, China

\section{*Correspondence:} \\ Liz M. Díaz-Vázquez, Lab CN 202A \\ Department of Chemistry, University \\ of Puerto Rico Rio Piedras Campus, \\ Barbosa Ave-Ponce de León Avenue, \\ San Juan, PR 00931, USA \\ e-mail: limdiaz@uprrp.edu; \\ lizvazquez8@gmail.com
}

Algae biomasses are considered a viable option for the production of biofuel because of their high yields of oil produced per dry weight. Brown macroalgae Sargassum spp. are one of the most abundant species of algae in the shores of Puerto Rico. Its availability in large quantity presents a great opportunity for use as a source of renewable energy. However, high ash content of macroalgae affects the conversion processes and the quality of resulting fuel products. This research studied the effect of different demineralization treatments of Sargassum spp. biomass, subsequent hydrothermal liquefaction (HTL), and bio-oil characterization. Demineralization constituted five different treatments: nanopure water, nitric acid, citric acid, sulfuric acid, and acetic acid. Performance of demineralization was evaluated by analyzing both demineralized biomass and HTL products by the following analyses: total carbohydrates, proteins, lipids, ash content, caloric content, metals analysis, Fourier transform infrared-attenuated total reflectance spectroscopy, energy dispersive spectroscopy, scanning electron microscopy, and GCMS analysis. HTL of Sargassum spp. before and after citric acid treatment was performed in a $1.8 \mathrm{~L}$ batch reactor system at $350^{\circ} \mathrm{C}$ with a holding time of $60 \mathrm{~min}$ and high pressures (5-21 MPa). Demineralization treatment with nitric acid was found the most effective in reducing the ash content of the macroalgae biomass from 27.46 to $0.99 \%$ followed by citric acid treatment that could reduce the ash content to $7 \%$. Citric acid did not show significant leaching of organic components such as carbohydrates and proteins, and represented a less toxic and hazardous option for demineralization. HTL of untreated and citric acid treated Sargassum spp. resulted in bio-oil yields of $18.4 \pm 0.1$ and $22.2 \pm 0.1 \%$ (ash-free dry basis), respectively.

Keywords: Sargassum spp., demineralization, hydrothermal liquefaction, macroalgae bio-oil, biomass conversion

\section{INTRODUCTION}

Currently, bio-oil obtained from algae is considered a promising alternative to fossil fuels due to its high energy content (Azadi et al., 2014; Brownbridge et al., 2014) and low life-cycle emissions of greenhouse gases (Li et al., 2011; Azadi et al., 2014). Algae biomass (both microalgae and macroalgae/seaweeds) has higher lipid content and energy content than most lignocellulosic biomass (wood, plants) used for biofuels (Ross et al., 2008). In addition, macroalgae, in particular, are able to regenerate continuously without any special nutrition (Nautiyal et al., 2014; Venteris et al., 2014). In contrast to the high lignocellulosic contents of terrestrial flora, macroalgae are primarily composed of elastic polysaccharides such as alginic acid, laminarin, carrageenan, and agarose that make macroalgae a more suitable feedstock for thermochemical conversion processes (Guiry and Blunden, 1991; Holdt and Kraan, 2011). Recent studies have demonstrated that higher calorific value products can be obtained from macroalgae through hydrothermal liquefaction (HTL) (Peterson et al., 2008; Jena et al., 2011; Toor et al., 2011).
Hydrothermal liquefaction is a process used to obtain bio-crude from wet biomass in moderate to high temperatures $\left(280-370^{\circ} \mathrm{C}\right)$ and pressures (10-25 Mpa) (Villadsen et al., 2012), in which water in its subcritical state acts as a highly reactive medium and catalyzes many chemical reactions (Toor et al., 2011). This process is fast and eco-friendly (Peterson et al., 2008) and is energetically efficient because it does not include a drying step as in the pyrolysis process (Bridgwater et al., 1999; Jena and Das, 2011). High reactivity and superior ionic product $\left(K_{w}\right)$ of subcritical water break down biomass complex polymers including polysaccharides, lipids, and proteins into simpler molecules that can be converted into bio-oils with different viscosities (Peterson et al., 2008; Villadsen et al., 2012) depending on the catalysts, solvents, feedstock composition, and pretreatment methods employed. (Zhuang et al., 2012; Neveux et al., 2014; Singh et al., 2015).

Brown macroalgae, Sargassum ssp., are considered as a potential biomass source for energy production due to their relatively fast growth rates, ease of harvesting, and low preproduction cost (Guo et al., 2012). Sargassum fluitans, S. natans, and S. filipendula 
are three of the most abundant macroalgae species found at Puerto Rico's coasts. The lipids content of Sargassum spp. ranges between 1.0 and $2.5 \%$ (total lipids). Li et al. (2012) reported the use of Sargassum patens C. Agardh biomass to generate bio-oil via HTL. They reported a bio-oil yield of $(32.1 \pm 0.2) \% \mathrm{wt}$./wt. as dry algae basis) with a calorific value of $27.1 \mathrm{MJ} / \mathrm{kg}$. Another study on HTL of brown algae Saccharina ssp. reported a yield of 8.7 and $27.7 \%$ of bio-oil depending on the harvest times and harvesting conditions of the macroalgae (Elliott et al., 2013). Blue-green algae and red macroalga (Porphyra tenera) have also been investigated for its bio-oil production through pyrolysis procedures, resulting in a similar calorific values as $S$. patens but with higher yields employing temperatures of $500^{\circ} \mathrm{C}$ (Bae et al., 2011; Hu et al., 2013). A recent research report described hydrothermal treatments for six types of green algae (Chlorophyta) (Neveux et al., 2014) that produced lower bio-oil yield, 9.7 to $26.2 \%$, of bio-oil than the reported yield for Sargassum patents C. Agardh.

Although HTL has the potential to generate high yields of bio-oil, there are some limitations that need to be addressed if macroalgae biomass is used as feedstock. One of the major limitations of using macroalgae to produce biofuels is their high ash content (up to 50\%), which reduces the yield and quality of the generated bio-oils and restricts their use in direct combustion and gasification processes (Bach et al., 2014; Neveux et al., 2014). The high ash content of macroalgae is due to the presence of inorganic salts and metals. The effect of inorganic content on the thermal conversion of terrestrial biomass has been well studied and documented; however, the effect of ash content on HTL conversion of marine feedstocks such as macroalgae is not well known (Rowbotham et al., 2013). It is expected that the high inorganic content in macroalgae will affect the physicochemical characteristics of HTL bio-oil and its storage through the catalysis of polymerization reactions.

Most alkali and alkaline earth metals present in algae can either play a catalytic role or act as inhibitors during thermochemical conversions. Ross et al. (2008) reported that the high content of alkaline metals in macroalgae impacted negatively the quality and yield of bio-crude during pyrolysis. There is a need to remove (or reduce) most of the inorganic elements in the biomass. To lower the inorganic content, Ross et al. (2009) employed two demineralization pretreatments of three brown algae species: washing the biomass with nanopure water and with hydrochloric acid solution. It was found that $\mathrm{HCl}$-demineralization treatment was more effective in reducing the amount of metals and increasing the caloric value of the generated pyrolysis product. Shakirullah et al. (2006) published another demineralization study in which they employed chelating agents like EDTA and weak acids like citric acid for coal metal leaching. Their findings showed similar patterns and demineralization potential, removing $64 \%$ of the ash content without harm to the carbon content in the samples.

Bio-crudes generated from biomass require further refining by catalytic hydrodeoxygenation and cracking methods. High ash content in macroalgae can bring additional challenges to the catalytic refining of biofuel such as decrease in catalyst activities, poisoning, and coking (Bach et al., 2014; Neveux et al., 2014). It is reported that alkali and alkali earth metals present in lignocellulosic feedstocks inactivated the catalysts used in the downstream upgrading processes of bio-oil (Liu and Bi, 2011). Although it is already established that metal content impacts biomass thermochemical processing, their role and mechanisms are not well understood and have only been studied for a few types of feedstocks and biomass thermochemical conversion techniques (Liu and Bi, 2011; Jiang et al., 2013).

In this article, we investigate the impacts of different demineralization treatments of macroalgae biomass. Five different treatments were selected for the study: two strong acids (nitric and sulfuric acid), two weak acids (citric and acetic acid), and nanopure water. Due to its abundance in Puerto Rico coast, Sargassum spp. were selected for the study. The study focused on analysis of the biomass changes in its physical-chemical composition, and the impact of the pretreatment on the bio-oil yield through the HTL process. The pre-treated and non-treated Sargassum spp. biomass were analyzed and compared for their metal contents and organic composition. The quality and chemical composition of the generated bio-oil from untreated and demineralized biomass were compared in terms of energy content and higher heating values (HHVs).

\section{MATERIALS AND METHODS RAW MATERIAL}

Sargassum spp. (a mixture of S. fluitans, S. natans, and S. filipendula) were collected from Naguabo, Puerto Rico, located on the south-east coast of the island facing the Caribbean Sea and Toa Baja, Puerto Rico, located on the north of the island facing the Atlantic Ocean during March-June, 2012. Impurities and salts were removed using nanopure Milli-Q water. Macroalgae biomass was dried at $60^{\circ} \mathrm{C}$, pulverized and milled for $6 \mathrm{~min}$ using an $8000 \mathrm{M}$ mixer/mill (SPEX CertiPrep, Metuchen, NJ, USA) and stored in a desiccator at room temperature until further analysis.

\section{DEMINERALIZATION METHOD}

Demineralization procedures were adapted from the study reported by Jiang et al. (2013). Sargassum spp. biomass was submitted to five different demineralization treatments: nanopure Milli-Q water, sulfuric acid (10\% v/v), nitric acid ( $10 \% \mathrm{v} / \mathrm{v})$, acetic acid $(10 \% \mathrm{v} / \mathrm{v})$, and citric acid $(10 \% \mathrm{w} / \mathrm{v})$. All acids were $99.9 \%$ pure and were purchased from Sigma Aldrich. Acid solutions were prepared using nanopure Milli-Q water. In a typical demineralization treatment, $8.0 \mathrm{~g}$ of biomass were immersed in $100 \mathrm{~mL} 10 \%$ acid solution (or, just water) to obtain sludge. Algae sludge was magnetically stirred at $28^{\circ} \mathrm{C}$ and $1000 \mathrm{rpm}$ for $12 \mathrm{~h}$. After demineralization, the samples were filtered and rinsed with an excess of nanopure Milli-Q water until the $\mathrm{pH}$ value was neutral. Treated biomass samples were dried in an electric oven at $60^{\circ} \mathrm{C}$ overnight and stored in a sealed desiccator until further analysis. Demineralization treatments and analyses were done in triplicate and mean values are reported.

\section{BIOMASS CHARACTERIZATION \\ Biomass biochemical analysis}

Untreated and treated Sargassum biomass was analyzed for soluble carbohydrates, total proteins, and total lipids content. Anthrone method (Hedge and Hofreiter, 1962), a colorimetric assay, was used to determine the total soluble carbohydrates content as follows: $0.1 \mathrm{~g}$ of dry algae was heated in $10 \mathrm{~mL} \mathrm{HCl} 2.5 \mathrm{M}$, filtered 
and neutralized using $\mathrm{NaHCO}_{3}$ until neutral $\mathrm{pH} ; 1 \mathrm{~mL}$ of the resulting solution was mixed with $2 \mathrm{~mL}$ of aqueous solution $75 \%$ $\mathrm{H}_{2} \mathrm{SO}_{4}$ and $4 \mathrm{~mL}$ of anthrone solution. The absorbance was read at $630 \mathrm{~nm}$ using a ultraviolet-visible spectrophotometer (Hach Dr5000). Algal proteins were extracted by a mild digestion using $0.6 \mathrm{M}$ sodium hydroxide solution at $40^{\circ} \mathrm{C}$ for $12 \mathrm{~h}$. The extracts were filtered, dialyzed against nanopure water for $48 \mathrm{~h}$, and then lyophilized. The protein content in algal biomass was determined by bicinchoninic acid (BCA) assay (Wiechelman et al., 1988) and measured at $562 \mathrm{~nm}$. The total lipid content (\%) was determined using an adaptation of the method reported by Bligh and Dyer (1959). Briefly, $1 \mathrm{~g}$ of the biomass was homogenized using $15.0 \mathrm{~mL}$ of a mixture of solvents [chloroform/(methanol/water) 3:1] using a tissue grinder (Omni ${ }^{\circledR}$ Tissue Master, 125 Watt-Lab Homogenizer with a $7 \mathrm{~mm}$ probe tip). Then the homogenate was transferred to a separation funnel and $15 \mathrm{~mL}$ of chloroform were added. The aqueous phase was discarded; the organic extract was collected and evaporated to dryness in weighed vials to determine the total lipid content of the sample.

\section{Proximate and metal analysis of untreated and treated Sargassum biomass}

Moisture, ash, volatile (dry), and fixed carbon contents of untreated macroalgae and solid residues (bio-char) were measured using a thermogravimetric analyzer (TGA), (Leco TGA-701, Leco Corp.) following the ASTM D-5142 method: 1 g sample was heated until $900^{\circ} \mathrm{C}$ at a rate of $50^{\circ} \mathrm{C} / \mathrm{min}$. For metal analysis, $100 \mathrm{~mL}$ of algae solutions were prepared by adding $0.5 \mathrm{~g}$ of samples and were digested in $35 \mathrm{~mL}$ of concentrated $69.6 \%$ Nitric acid (Fisher scientific, USA) solution. Standard solutions and samples were analyzed in an atomic absorption spectrometer (Perkin Elmer AA analyst 200). Biomass samples were also analyzed using energy dispersive spectroscopy (EDS) X-ray fluorescence (EDAX Detecting Unit PV7757/81 ME) to determine elemental composition. Ash compositions of raw and treated biomass were determined through the use of a muffle furnace. Briefly, three $1.00 \mathrm{~g}$ samples of each dry algae biomass were weighed in crucibles and then heated in a muffle furnace at $600^{\circ} \mathrm{C}$ for $6 \mathrm{~h}$ as reported by Ververis et al. (2007). After cooling the samples in a desiccator, the ash content (\%) was determined. Results were expressed on a dry algae basis.

\section{Internal energy change $(\Delta U)$ of macroalgae biomass}

The internal change of energy $(\Delta U)$ associated with combustion of the Sargassum spp. biomass in the presence of excess oxygen was measured using a bomb calorimeter. The reaction was carried out experimentally in a closed, constant-volume calorimeter (Parr 1341 Plain Jacket Oxygen Bomb 2901EB Ignition unit 115/50/60) and the experimentally measured quantity was the heat associated with the process. Since the change in internal energy is equal to the heat at a constant volume $\left(\Delta U=q_{\mathrm{V}}\right)$, a measurement of the heat gives $\Delta U$ of the combustion reaction directly. The internal energy of combustion was determined from the heat capacity of the system and the temperature rise. All the calculations were done as indicated on the instrument manual and as reported by Garland et al. (2009). The calorimeter calibration and its heat capacity ( $\left.C_{\text {calorimeter }}\right)$ calculation were performed using benzoic acid as the reference standard.

\section{FTIR-ATR characterization analysis of macroalgae biomass}

Untreated and demineralization treated samples were analyzed using Fourier transform infrared-attenuated total reflectance spectroscopy (FTIR-ATR) (Perkin Elmer Spectrum 100 FTIR spectrometer) to identify the chemical structural differences due to the demineralization processes. For this analysis, $2 \mathrm{mg}$ of sample was ground to obtain a particle size of $\sim 150 \mu \mathrm{m}$. The attenuated total reflectance infrared absorption spectra of the samples were recorded in the frequency range of $4000-450 \mathrm{~cm}^{-1}$ and 40 scans were recorded at a resolution of $4 \mathrm{~cm}^{-1}$. Three absorption spectra were obtained for each sample and the average spectra are reported.

\section{Scanning electron microscopy analysis}

The morphology and surface of gold coated biomass were studied by scanning electron microscopy (SEM) [(JEOL, JSM 6480LV) with low vacuum at $20 \mathrm{kV}$ and $2000 \times$ magnification factor to determine its potential change to the physical structure of the macroalgae.

\section{HYDROTHERMAL LIOUEFACTION METHODOLOGY}

Hydrothermal liquefaction experiments were carried out in a $1.8 \mathrm{~L}$ batch reactor system (Parr Instruments Co. Moline, PA, USA) at $350 \pm 5^{\circ} \mathrm{C}$ with a holding time of $60 \mathrm{~min}$ and stirred at $300 \mathrm{rpm}$ as reported by Jena et al. (2011) (Jena and Das, 2011). Algal slurry was prepared using $80 \%$ deionized water and $20 \%$ dry algae biomass by weight. In a typical experiment, homogenized algal slurry $(\sim 500 \mathrm{~g})$ was loaded in the reactor and sealed. The system was purged with $\mathrm{He}$ for $3 \mathrm{~min}$ and pressurized to $2.03 \mathrm{MPa}$ $(295 \pm 2$ psi). At the end of the reaction, the reactor was cooled down using tap water flowing through an internal cooling coil that was regulated by a solenoid valve. Gas products were collected in Tedlar ${ }^{\circledR}$ sample bags. HTL products were separated into bio-oil fraction, water soluble fraction, solid residues, and gaseous fraction (Figure 1). The rotor, reactor, and solids residues were washed using dichloromethane (DCM), Sigma Aldrich, USA. The solid product was removed by filtration and the liquid phase product was separated by liquid-liquid extraction. Bio-oil and water soluble products were stored in glass bottles in darkness at $4^{\circ} \mathrm{C}$ and solids residues (bio-char) were oven dried at $50^{\circ} \mathrm{C}$ for $24 \mathrm{~h}$ and stored for further analysis. All HTL experiments were performed in duplicate.

\section{Analysis of HTL products}

Bio-oil and bio-char were analyzed by FTIR-ATR using the procedure described in Section "FTIR-ATR Characterization Analysis of Macroalgae Biomass" for solid samples. For liquid samples, a drop was employed in the same analysis. Elemental $\mathrm{C}, \mathrm{H}, \mathrm{N}$, $\mathrm{S}$, and $\mathrm{O}$ contents in bio-oil and bio-char were measured using a LECO brand (Model CHNS-932) analyzer. Gas chromatography and mass spectroscopy (GC/MS) analysis of bio-oil samples and water soluble products was carried out with an Agilent Technologies 6890N Network GC system, 5973 Network Mass selective Detector and Agilent JW Scientific, DB-5 GC column (5\% phenyl and $95 \%$ methylpolysiloxane $30 \mathrm{~m} \times 0.25 \mathrm{~mm} \times 0.32 \mathrm{~mm}$ ). The gas fractions were analyzed by gas chromatography coupled to a thermal conductivity detector (GC-TCD Agilent Technologies 


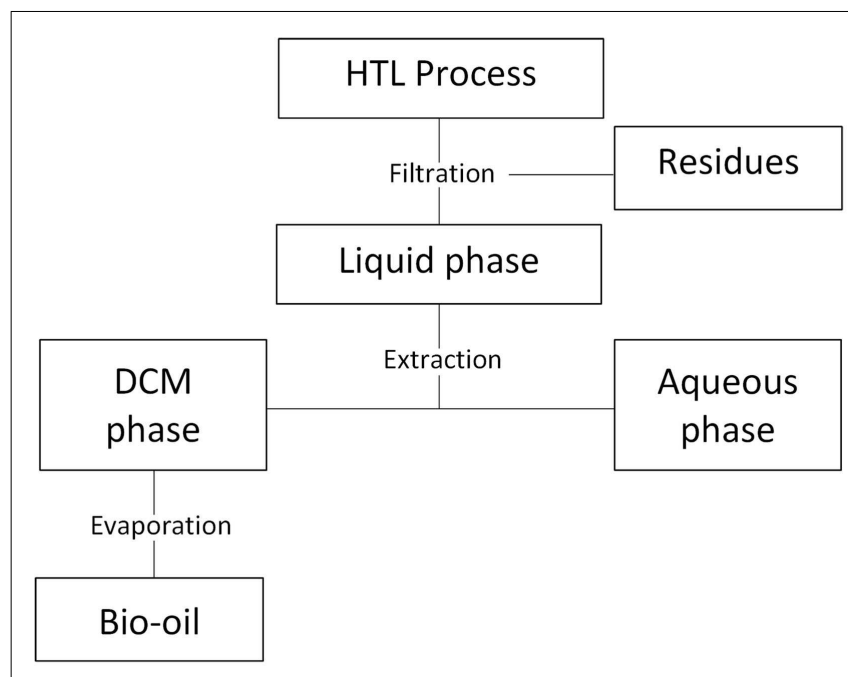

FIGURE 1 | Hydrothermal liquefaction process and product separation.

G2858A) with a column (5A PLOT) of $10 \mathrm{~m} \times 0.32 \mathrm{~mm}$ size and using Helium as mobile phase.

Bio-oil and water soluble product GC/MS procedures. Profiles of volatile and semivolatile compounds present in the bio-oil and residual water samples were analyzed by a gas chromatograph coupled to a mass spectrometer (Agilent Technologies 6890N Network GC system, 5973 Network Mass selective Detector). Bio-oil samples were submitted to a derivitization procedure to improve the detection of alcohol and fatty acids. Briefly, $10 \mathrm{mg}$ of bio-oil were added in a $5 \mathrm{~mL}$ reaction vessel with an excess of a silylating reaction mix [BSTFA ( $\mathrm{N}, \mathrm{O}$-bis (trimethylsilyl) trifluoroacetamide) and TMCS (trimethylchlorosilane) SUPELCO; Sigma Aldrich]. The reaction mixtures were incubated at $70^{\circ} \mathrm{C}$ for $30 \mathrm{~min}$. After the derivatization procedure, the samples were diluted to $2.00 \mathrm{~mL}$ with DCM and an aliquot of $1 \mu \mathrm{L}$ was analyzed by GC/MS. The GC/MS method was as follows: sample injection splitless, inlet temperature at $250^{\circ} \mathrm{C}$, pulse pressure $25 \mathrm{psi}$, and flow $1 \mathrm{~mL} / \mathrm{min}$; Column DB-5 $30 \mathrm{~m} \times 0.320 \mathrm{~mm}$ and film $0.21 \mu \mathrm{m}$. The MS was in positive ion and total ion scan mode. The GC oven temperature program was as follows: held at initial temperature at $70^{\circ} \mathrm{C}$ for $1 \mathrm{~min}$, then $5^{\circ} \mathrm{C} / \mathrm{min}$ until $120^{\circ} \mathrm{C}$, followed by an increase of $8^{\circ} \mathrm{C} / \mathrm{min}$ until $260^{\circ} \mathrm{C}$ where it was held for $5 \mathrm{~min}$.

In order to determine the compounds present in the water soluble aqueous co-product (ACP), ACP samples were preconcentrated using solid phase extraction technique with a $12 \mathrm{cc}$ Oasis ${ }^{\mathrm{TM}}$ HLB copolymer with hydrophilic lipophilic balance (HLB) Vac cartridge (Waters Co.) as a stationary phase. About $100 \mathrm{~mL}$ of ACP sample was passed through the cartridge; retained compounds were eluted using $10 \mathrm{~mL}$ of ethyl acetate and then preconcentrated with an inert flow of nitrogen to $2.00 \mathrm{~mL}$. Samples were derivatized using the same procedure used for bio-oil samples using BTSFA-TMCS as the silylating agent. The GC/MS method was the same as for bio-oil with the follows changes in the oven temperature program: initial temperature at $40^{\circ} \mathrm{C}$ held by $2 \mathrm{~min}$, and ramped at $40^{\circ} \mathrm{C} / \mathrm{min}$ until $100^{\circ} \mathrm{C}, 2^{\circ} \mathrm{C} / \mathrm{min}$ until $120^{\circ} \mathrm{C}$, $30^{\circ} \mathrm{C} / \mathrm{min}$ until $200^{\circ} \mathrm{C}, 15^{\circ} \mathrm{C} / \mathrm{min}$ until $260^{\circ} \mathrm{C}, 30^{\circ} \mathrm{C} / \mathrm{min}$ until 300 , and held for $3 \mathrm{~min}$ at that temperature. For bio-oil and water soluble analyses, compounds were identified using a NIST library; only the compounds with a quality identification ( $\mathrm{R}$ match) of $70 \%$ or more and a signal to noise $(\mathrm{S} / \mathrm{N})$ ratio $\geq 15$ were reported.

Calculation methods: bio-oil and bio-char yield, higher heating value, and energy recovery. Bio-oil and bio-char product yields were calculated separately on an ash and moisture free dry weight basis using the following equation (Li et al., 2012):

$$
Y_{\text {PRODUCT }}=\left[\frac{W_{\text {PRODUCT }}}{W_{\text {FEEDSTOCK }}-W_{\text {ASH }}-W_{\text {MOISTURE }}}\right] \times 100
$$

where, $Y_{\text {PRODUCT }}$ is the bio-oil or bio-char yield (wt.\%) on a dry weight basis, $W_{\text {PRODUCT }}$ is the mass of product $(\mathrm{g}), W_{\text {FEEDSTOCK }}$ is the mass of macroalgae biomass used in the reactor, $W_{\mathrm{ASH}}$ and $W_{\text {MOISTURE }}$ are the ash content and moisture content of the feedstock, respectively. The HHVs of the generated bio-oil and bio-char were calculated using the proximate analysis results and the Dulong formula (Landau and Lifshitz, 1980; Qu et al., 2003):

$$
\operatorname{HHV}(\mathrm{MJ} / \mathrm{kg})=0.3383 \mathrm{C}+1.422(\mathrm{H}-\mathrm{O} / 8)
$$

where $\mathrm{C}, \mathrm{H}, \mathrm{O}$ are the wt.\% present in the product.

The chemical energy recovery (ER) was calculated for the biocrude and bio-char phase according to the following equation (Neveux et al., 2014):

$$
\mathrm{ER}=\left(\frac{\left(H H V_{\text {PRODUCT }} \times W_{\text {PRODUCT }}\right)}{\left(H H V_{\text {FEEDSTOCK }} \times W_{\text {FEEDSTOCK }}\right)}\right) \times 100
$$

\section{RESULTS AND DISCUSSION EFFECTS OF DEMINERALIZATION ON BIOMASS COMPOSITION AND BIO-OIL YIELD Material recovery, biochemical composition, and internal energy}

The effectiveness of the different biomass demineralization treatments was evaluated considering the impact of the treatments on the biochemical composition of the algae. The yield of bio-oil in HTL depends on the amount of biomolecules such as carbohydrates, proteins, and lipids present in the biomass. Therefore, the most effective treatment should be able to reduce the mineral content of the biomass without losing these molecules. Table 1 summarizes the impact of the demineralization treatments on the biomass composition. From Table 1, it can be concluded that all treatments significantly decrease the biomass ash contents; however, they also reduce the total soluble carbohydrates and total proteins in the biomass. An average total biomass reduction of $36 \%$ was observed for all treatments. On the other hand, the percent of lipids extracted from the biomass after the demineralization treatments were higher than with the untreated biomass. This increase in the effectiveness of lipid extraction may be caused by the breakdown of the cellular walls of the macroalgae during the treatments, which makes intracellular lipids more accessible. The treatments did not increase the amount of lipids present in the algae, they maybe just make the extraction process more effective and it is shown in the $\%$ of recovery obtained. 
Table 1 | Recovery percentage, chemical content and changing in internal energy of algae biomass after the demineralization treatment (all values are reported on dry biomass basis).

\begin{tabular}{|c|c|c|c|c|c|c|}
\hline $\begin{array}{l}\text { Demineralization } \\
\text { treatment }\end{array}$ & $\begin{array}{l}\% \text { Recovery } \\
\text { biomass }\end{array}$ & $\begin{array}{l}\text { Soluble carbohydrates } \\
\text { (w/w \%) }\end{array}$ & $\begin{array}{l}\text { Ash content } \\
(w / w \%)\end{array}$ & $\begin{array}{l}\text { Proteins } \\
\text { (w/w \%) }\end{array}$ & $\begin{array}{l}\text { Lipids } \\
\text { (w/w \%) }\end{array}$ & $\begin{array}{l}(-\Delta U) \\
\mathbf{k J} / \mathbf{g}\end{array}$ \\
\hline No treatment & $\mathrm{N} / \mathrm{A}$ & $10 \pm 2$ & $27.46 \pm 0.04$ & $11.3 \pm 0.4$ & $0.3 \pm 0.1$ & $11.4 \pm 0.2$ \\
\hline Nanopure water & $61 \pm 7$ & $8.3 \pm 0.8$ & $12.5 \pm 0.4$ & $10.9 \pm 0.5$ & $0.7 \pm 0.3$ & $11.9 \pm 0.4$ \\
\hline Acetic acid & $66 \pm 3$ & $9 \pm 1$ & $10.4 \pm 0.5$ & $8.1 \pm 0.7$ & $0.4 \pm 0.5$ & $11.9 \pm 0.4$ \\
\hline Citric acid & $67 \pm 3$ & $9 \pm 1$ & $7 \pm 1$ & $9.4 \pm 0.4$ & $0.9 \pm 0.4$ & $13.0 \pm 0.1$ \\
\hline Nitric acid & $60 \pm 2$ & $9 \pm 2$ & $0.99 \pm 0.07$ & $8.1 \pm 0.5$ & $0.9 \pm 0.4$ & $14.0 \pm 0.3$ \\
\hline Sulfuric acid & $65 \pm 6$ & $7 \pm 4$ & $9 \pm 0.5$ & $6.9 \pm 0.4$ & $0.9 \pm 0.5$ & $12.3 \pm 0.9$ \\
\hline
\end{tabular}

$N / A$, not applicable; $-\Delta U$, internal energy.

Among all demineralization treatments conducted in this study, nitric acid was found to be the most effective in reducing the ash contents from $27.64 \%$ in the starting biomass to $0.99 \%$, followed by citric acid that resulted in $7 \%$ ash content in the treated biomass. These treatments also resulted in lower reduction of soluble carbohydrates and proteins contents, and higher energy content $(\Delta U)$ (Table 1). Even nanopure water treatment was able to reduce the ash content significantly suggesting that part of the mineral content lost from Sargassum, is composed of water soluble components such as chlorides, nitrates, carbonates, and phosphates as observed for terrestrial biomass (Patwardhan et al., 2010; Jiang et al., 2013).

From Table 1, it can be seen that all demineralization treatments resulted in similar biomass recovery. The change in internal energy $(-\Delta U)$ associated with the combustion reaction of the algae biomass was determined by the calorimetric analysis. The change in internal energy was used to estimate the amount of energy the biomass may release. The calorimetric analysis results showed that demineralized biomass releases a higher amount of energy during its combustion. The biomass demineralized with nitric acid releases the highest amount of energy. It may be due to the fact that the removal of the inorganic components allows a more complete combustion of the organic components of the biomass. Also, de-ashing properties of nitric acid solutions have been shown in the demineralization of different types of coals, which is related to a more aggressive digestion (Shakirullah et al., 2006).

\section{Metal analysis of treated and untreated biomass}

Treated and untreated Sargassum biomass was analyzed for copper $(\mathrm{Cu})$, iron $(\mathrm{Fe})$, magnesium $(\mathrm{Mg})$, manganese $(\mathrm{Mn})$, sodium $(\mathrm{Na})$, and zinc $(\mathrm{Zn})$ content using an atomic absorption (AA) spectrometer. Biomass was analyzed before and after each demineralization (Table 2). The metal content was reduced in the treated biomass for all demineralization treatments. The inorganic acid, sulfuric acid was the most effective treatment in removing $\mathrm{Cu}, \mathrm{Fe}, \mathrm{Mn}$, and $\mathrm{Zn}$ and was followed by another inorganic acid, nitric acid. The organic acids, citric and acetic acid, were found to be effective treatments for the removal of $\mathrm{Mg}$ and $\mathrm{Mn}$.

Other elements ( $\mathrm{Na}, \mathrm{K}, \mathrm{Si}, \mathrm{P}$, and $\mathrm{S}$ ) were analyzed using electron dispersive spectroscopy (EDS) and are presented in Table 2. The EDS results also confirmed the reduction in inorganic contents of the biomass in the demineralization treatments. Both EDS and AA
Table 2 | Elemental analysis in untreated and treated biomasses.

\begin{tabular}{|c|c|c|c|c|c|c|}
\hline Treatment & $\begin{array}{l}\text { No } \\
\text { treatment }\end{array}$ & $\begin{array}{l}\text { Nanopure } \\
\text { water }\end{array}$ & $\begin{array}{l}\text { Acetic } \\
\text { acid }\end{array}$ & $\begin{array}{l}\text { Nitric } \\
\text { acid }\end{array}$ & $\begin{array}{l}\text { Citric } \\
\text { acid }\end{array}$ & $\begin{array}{l}\text { Sulfuric } \\
\text { acid }\end{array}$ \\
\hline \multicolumn{7}{|c|}{ AA RESULTS (ppm) } \\
\hline $\mathrm{Cu}$ & 38.5 & 24 & 12 & n.d & 13 & n.d \\
\hline $\mathrm{Fe}$ & 414.6 & 403 & 346 & n.d & 440 & n.d \\
\hline $\mathrm{Mg}$ & 21,870 & 21,663 & n.d & 789.7 & n.d & 503 \\
\hline $\mathrm{Mn}$ & 53 & 48 & n.d & n.d & n.d & n.d \\
\hline Zn & 73 & 82 & 71 & 6 & 36 & 13 \\
\hline \multicolumn{7}{|c|}{ EDS RESULTS (ppm) } \\
\hline $\mathrm{Na}$ & 1800 & 1300 & 400 & n.d & n.d & 1100 \\
\hline K & 8000 & 8400 & n.d & n.d & 700 & n.d \\
\hline $\mathrm{Si}$ & 1700 & 1300 & n.d & 1000 & 1300 & 1300 \\
\hline$P$ & 400 & n.d & n.d & n.d & n.d & n.d \\
\hline S & 11,600 & 10,900 & 11,500 & 700 & 9650 & $60,400^{a}$ \\
\hline
\end{tabular}

n.d: below detection limits or not detected.

${ }^{a}$ Expected to be high.

results confirmed the reduction of alkali and alkaline earth metals concentration in Sargassum biomass after the treatments.

Treatment of biomass in strong acids is an efficient method for removal of the inorganic elements of the feedstock before its HTL conversion into bio-oil. However, the treatment could also affect the structural and physicochemical properties of the sample. The treatments with weak acids such as citric and acetic acid are less effective than the treatment with strong acids, but are less aggressive removing the organic content of the biomass.

\section{CHARACTERIZATION OF BIOMASS FTIR-ATR characterization analysis}

Fourier transform infrared-ATR analysis was performed to obtain more information on the chemical composition differences in untreated and demineralized Sargassum biomass. Figure 2 shows the IR spectra of untreated and treated biomass. Results obtained from FTIR-ATR analysis confirmed that after the demineralization process, the same types of chemical compounds were still present in all treated solids, although FTIR results also revealed that some of the treatments showed losses of structural compounds features. These results agreed with our biochemical composition analysis reported in Table 1. In the mid-infrared spectra, a prominent band 


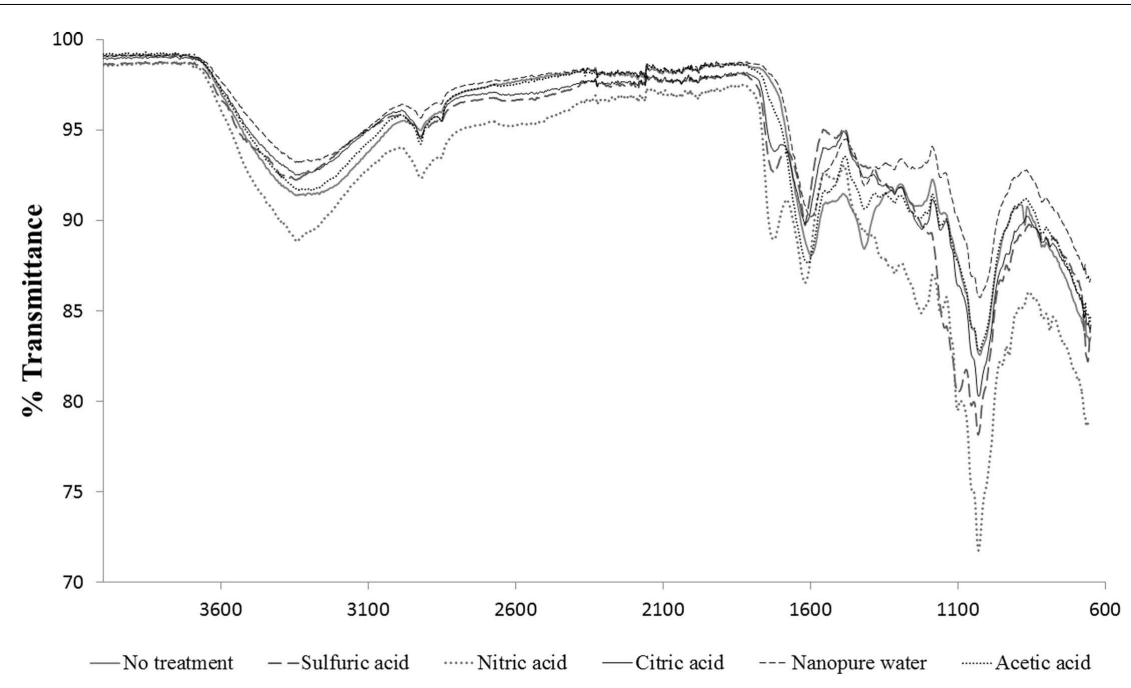

Wave number $\left(\mathrm{cm}^{-1}\right)$

FIGURE 2 | Fourier transform infrared spectra of Sargassum biomasses after demineralization processes

at $3000-3700 \mathrm{~cm}^{-1}$ was attributed to $\mathrm{O}-\mathrm{H}$ stretching vibrations of hydroxyl functional groups in carboxylic, phenolic, and alcoholic compounds. The band at $2800-3000 \mathrm{~cm}^{-1}$ was related to $=\mathrm{C}-$ $\mathrm{H}$ and $\mathrm{C}-\mathrm{H}$ stretching vibrations. Intensities of the above bands decreased in almost all the solid samples from demineralization treatment, except for the nitric acid treatment. The increase of this band height can be attributed to the presence of residues of nitric acids in the treated samples showing a narrower band in the region of 3491-3550 $\mathrm{cm}^{-1}$. Another relevant band that appeared at a frequency of $1725 \mathrm{~cm}^{-1}$, is attributed to the $\mathrm{C}=\mathrm{O}$ stretching vibration of free carbonyl groups present in lipids and some polysaccharides such as alginate.

The bands peaks in the region, $1370-1320 \mathrm{~cm}^{-1}$ were attributed to $\mathrm{O}-\mathrm{H}, \mathrm{C} \equiv \mathrm{C}$, and $\mathrm{C}=\mathrm{O}$ stretching vibrations. The band height at $1350 \mathrm{~cm}^{-1}$ decreased with all demineralization treatments. Some bands were observed at $900-1200 \mathrm{~cm}^{-1}$, with the most intense band in this region corresponding to $\mathrm{C}-\mathrm{O}$ stretching, which might be associated with the polysaccharides (alginate, laminarin, and fucoidan) (Ross et al., 2009). Some of the observed bands were sharper for samples from acids demineralization treatments. The observed changes in this region could be attributed to changes in some of the major constituents due to cross linking reactions between $\mathrm{C}-\mathrm{OH}, \mathrm{C}-\mathrm{O}-\mathrm{C}$, and other reactive functional groups present in the biomass (Mayer et al., 2012). The breakdown and leaching of some polysaccharides is suggested from the increase of the bands at $900-1200 \mathrm{~cm}^{-1}$. Similar behavior has also been in terrestrial biomass (Jiang et al., 2013).

\section{Biomass surface analysis (SEM)}

Scanning electron microscopy was used to study changes in the biomass surface due to demineralization pretreatments. The SEM micrographs are shown in Figure 3. The micrographs showed that treated algae biomass materials were more porous than untreated algae, and showed distinct differences in the morphology. The untreated biomass showed a defined structure in which small
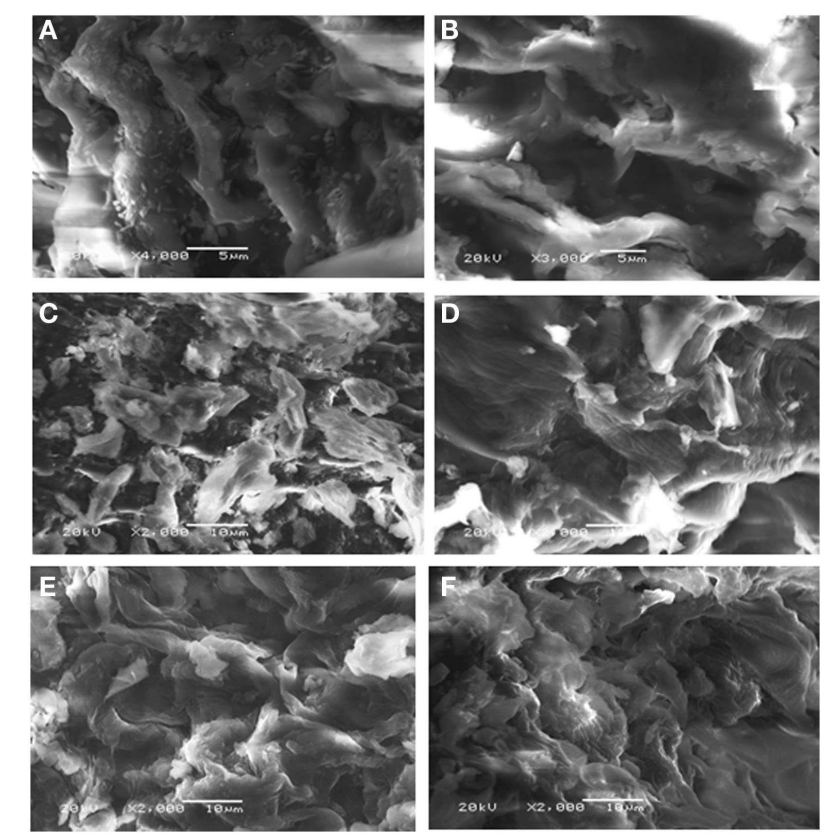

FIGURE 3 | Scanning electron microscopy micrographs showed the disruption of Sargassum biomass after the pretreatment with: (A) No treatment, (B) nanopure water, (C) acetic acid, (D) nitric acid, (E) citric acid, and (F) sulfuric acid.

particles were attached. The biomass treated with nanopure water, acetic acid, and citric acid still showed an almost intact surface when compared with the untreated biomass, but most of the small particles observed on the untreated biomass were removed; only the particles with larger dimensions were noticed on the surface. After treatment with strong acids (nitric acid and sulfuric acid), the structure of the biomass surface seemed to be wrinkled and 
fewer particles were seen adhering to the surface, as compared to the weak acid treatments. The changes in morphology of the biomass surface and the analysis of metal composition suggest that the particles observed at the surface of the biomass could be minerals. The strong acid treatment produced the most drastic change in fiber structure of the biomass, demineralization treatments were able to remove the minerals but at the same time they dissolved the polysaccharides (Jiang et al., 2013).

\section{HTL OF UNTREATED AND DEMINERALIZED SARGASSUM BIOMASS}

Although nitric acid was a better pretreatment for demineralizing the selected biomass, it could be associated with proteins and soluble carbohydrates losses, some structural harm and it is a toxic compound. It was not selected for these reasons and also because it is recommended to avoid the presence of nitrogen in the HTL process. Alvarez et al. (2003) found an increase in nitrogencontaining compounds in the demineralized coal employing nitric acid treatment that could be associated with the release of $\mathrm{NOx}$ during combustion. Although the citric acid demineralization pretreatment did not show the highest demineralization potential, it was selected for further HTL studies due to its low toxicity and its potential to remove inorganic components with a minimum loss of organic compounds (polysaccharides, proteins, and lipids) that are crucial for the HTL process.

\section{Biomass proximate analysis}

Proximate analysis of the untreated and demineralized algae biomass (treated with citric acid) was performed and resulted in higher fixed carbon percent $(19.0 \pm 1.0 \%)$ and lower ash content $(7.0 \pm 0.8 \%)$ than the untreated feedstock $(9.6 \pm 0.0 \%$ fixed carbon and $27.4 \pm 0.9 \%$ ash), suggesting that there is higher organic content in the same amount of treated feedstock. As mentioned earlier (see Effects of Demineralization on Biomass Composition and Bio-Oil Yield), demineralized biomass had a lower metal content in the ash. Also, the citric acid treated biomass had a higher percent of volatiles $(73.0 \pm 2.0 \%)$ and lower moisture content $(4.9 \pm 0.6 \%)$ than untreated Sargassum biomass $(61.5 \pm 0.9 \%$ volatiles and $13.3 \pm 0.2 \%$ moisture).

\section{Bio-oil and bio-char yield, higher heating value, and energy recovery}

Hydrothermal liquefaction reaction conditions of $350^{\circ} \mathrm{C}, 20 \%$ solids load, $300 \mathrm{rpm}$ and $60 \mathrm{~min}$ reaction time were selected following the settings reported by Jena et al. (2011) (Jena et al., 2011). Bio-oil yields from HTL citric acid treated and untreated
Sargassum biomass are presented in ash-free dry weight basis in Table 3. As anticipated from the proximate analysis, a higher biooil yield $(22.2 \%)$ was obtained from the HTL of demineralized Sargassum biomass than that of the raw biomass, which had a bio-oil yield of $18.4 \%$. This could be due to more organic content in the same amount of feedstock that validates the demineralization treatment performed. The resulting bio-oil had a HHV of 32.4 and $32.3 \mathrm{MJ} / \mathrm{kg}$ in the demineralized and control, respectively, which was significantly higher than that of the obtained by Li et al. (2012), 27.1 MJ/kg. There are no significant differences in elemental carbon, hydrogen, and oxygen composition in bio-oil samples obtained from the untreated and treated biomass (Table 3 ). Both untreated and demineralized biomass produce bio-oil with $\mathrm{C}, \mathrm{H}$, and $\mathrm{O}$ values comparable to the other studies reported in the literature for the liquefaction of algal biomass (\%C 70-73; \% $\mathrm{H}, 7-8$; $\% O$ 10-11; \%S 0-1; and \%N 1-7) (Zhou et al., 2010; Anastasakis and Ross, 2011). High oxygen content in bio-oil suggests that a catalysis process before or after the HTL process is required to convert the product in a useful fuel (Li et al., 2012).

Table 3 includes the values for bio-oil ER. A higher energy recovery value $(42.3 \pm 0.1) \%$ was obtained for the bio-oil obtained from the demineralized biomass, while only $(23.5 \pm 0.1)$ was obtained from the raw biomass. Given that the HHV was not altered, the increase in the ER value may be attributed to the increase in the yield production of bio-oil. Table 3 also shows that after citric acid treatment and HTL, bio-oil was obtained with slight increase of $\mathrm{C} / \mathrm{O}$. This confirms the increase in the potential energy output. Furthermore, $\mathrm{S}$ content was minimized, suggesting a more environmental friendly bio-oil product was obtained.

In contrast to the consistency of the elemental composition of the obtained bio-oil, bio-char composition was changed considerably between the untreated and the demineralized biomass as shown in Table 3. The untreated biomass produced an organic rich bio-char with higher carbon content $60 \%$, while the bio-char from the demineralized biomass had only $43.47 \% \mathrm{C}$. Therefore, a HHV was obtained for it $(20.7 \%)$ versus $11.5 \%$ for the biochar obtained from the demineralized biomass, suggesting that inorganic substances help preserve the energy output in bio-char although the total yield may be decreased. Although the HHV of bio-char has decreased, the $\mathrm{C} / \mathrm{O}$ content has also decreased. The reduction in $\mathrm{C}$ content in itself is not a desirable thing, but the increase in $\mathrm{O}$ is considered desirable because the presence of oxygenated groups in bio-char enhances its properties in soils applications - like its cation exchange capacity (CEC) - as reported in previous studies with terrestrial biomasses and production of

Table 3 | Ultimate analysis, product yield and energy recovery of HTL bio-crude and bio-char product obtained from untreated and demineralized Sargassum.

\begin{tabular}{|c|c|c|c|c|c|c|c|c|c|}
\hline \multicolumn{2}{|l|}{ Product } & \multirow{2}{*}{$\begin{array}{c}\text { Yield product (\%) } \\
22.2 \pm 0.1\end{array}$} & \multirow{2}{*}{$\begin{array}{c}\mathbf{C}(\%) \\
71.54 \pm 0.65\end{array}$} & \multirow{2}{*}{$\begin{array}{c}\mathbf{H}(\%) \\
8.05 \pm 0.29\end{array}$} & \multirow{2}{*}{$\begin{array}{c}\mathbf{N}(\%) \\
2.28 \pm 0.04\end{array}$} & \multirow{2}{*}{$\begin{array}{c}\mathbf{S}(\%) \\
0.07 \pm 0.09\end{array}$} & \multirow{2}{*}{$\begin{array}{c}\mathbf{O}(\%)^{\mathbf{b}} \\
18.05 \pm 0.92\end{array}$} & \multirow{2}{*}{$\begin{array}{c}\mathbf{H H V} \text { (MJ/kg) } \\
32.4 \pm 1.2\end{array}$} & \multirow{2}{*}{$\frac{\text { ER (\%) }}{42.3 \pm 0.1}$} \\
\hline Citric acid treated & Bio-oil & & & & & & & & \\
\hline biomass & Bio-char & 31.3 & $43.47 \pm 1.84$ & $3.67 \pm 0.35$ & $1.44 \pm 0.15$ & $4.18 \pm 2.16$ & $47.24 \pm 2.48$ & $11.5 \pm 2.5$ & $21.2 \pm 0.3$ \\
\hline \multirow[t]{2}{*}{ Untreated biomass } & Bio-oil & $18.4 \pm 0.1$ & $70.28 \pm 0.51$ & $8.31 \pm 0.01$ & $2.65 \pm 0.03$ & $0.21 \pm 0.05$ & $18.66 \pm 0.45$ & $32.3 \pm 0.6$ & $23.5 \pm 0.1$ \\
\hline & Bio-char & $29.3 \pm 0.1$ & $60.05 \pm 1.93$ & $4.08 \pm 0.05$ & $2.19 \pm 0.02$ & $3.04 \pm 0.55$ & $30.65 \pm 1.57$ & $20.7 \pm 3.0$ & $24.0 \pm 0.2$ \\
\hline
\end{tabular}

${ }^{a}$ Ash-free dry weight basis.

${ }^{b}$ Obtained by difference. 
char (Cheng et al., 2006). The C/O ratio of the produced bio-char suggest that it has a high number of oxygenated functional groups (phenol, hydroxyl, carboxyl among others), a property that can improve its chemisorption ability, increasing its potential to be used to remediate contaminated soils (Jose et al., 2013).

In summary for the HTL primary fuel target, the bio-oil, we observe an increase in yield, lower S, and slightly lower $\mathrm{N}$, along with an increase in ER after the demineralization pretreatment. The generated bio-char have a considerably high energy and higher carbon content than other algae bio-char (Li et al., 2012; Neveux et al., 2014), thus may be a valuable by-product if used for soil application [e.g., as a fertilizers or for remediation purposes (Bird et al., 2012)] or as a feedstock for subsequent thermochemical processes such as pyrolysis (López Barreiro et al., 2013). In terms of ER about $47.2 \%$ of the energy present in the original biomass was recovered in the form of bio-oil (19.6\%) and biochar $(27.6 \%)$ in the HTL of the demineralized biomass, while in the case of the untreated biomass only $28.3 \%$ of the energy was recovered. Part of the remaining chemical energy, in both cases may be present in the aqueous phase. As presented in the GCMS analysis of the aqueous residues that follows this section, in both cases there are compounds of energetic value present that may be recovered if a more efficient extraction of the aqueous phase is performed. The ER of the process was improved by the demineralization process, but it still needs to be increased. Our results point that the demineralization pretreatment may be of benefit for the bio-refinery.

\section{Bio-oil chemical composition}

ATR-FTIR analysis. The generated bio-oils were analyzed for their chemical composition with ATR-FTIR and the obtained spectra are presented in Figure 4. Peaks at 722, 737, and $819 \mathrm{~cm}^{-1}$, $\mathrm{O}-\mathrm{H}$ bending, shows the presence of aromatic compounds, phenols, esters, and ethers; at $1265 \mathrm{~cm}^{-1}, \mathrm{C}-\mathrm{O}$ stretching for alcohols and with peaks at 1383 and $1458 \mathrm{~cm}^{-1}, \mathrm{C}-\mathrm{H}$ bending, presence of fats; alkenes are detected at $1625 \mathrm{~cm}^{-1}, \mathrm{C}=\mathrm{C}$ stretching; ketones, aldehydes, and carboxylic acids with peak at $1688 \mathrm{~cm}^{-1}, \mathrm{C}=\mathrm{O}$ stretching; alkanes are found at 2875, 2932, and $2965 \mathrm{~cm}^{-1}, \mathrm{C}-\mathrm{H}$ stretching and water with the peak at $3375 \mathrm{~cm}^{-1}$. In the IRspectrum for the bio-oil obtained from the demineralized biomass, the bands that evidence the presence of alcohols, phenols, esters, ethers, and alkanes are more prominent than in the bio-oil of the raw biomass. Proximate analysis showed that the bio-oil from raw biomass had $1.3 \pm 0.7 \%$ of water, while the bio-oil from demineralized biomass had lower water content $0.8 \pm 0.4 \%$ w. It is consistent with the FTIR analyses where the band corresponding to $\mathrm{OH}$ was more prominent in the bio-oil from raw biomass.

GCMS analysis of the bio-oil product. In general, bio-oil generated from Sargassum biomass is a very complex blend of more than 100 compounds that were presumptively identified by GCMS. The chromatograms were analyzed with the NIST library and compounds having quality identification factor higher than 70 were reported. Table S1 in Supplementary Material section shows the compounds identified in the bio-oil obtained from the untreated and demineralized biomass, respectively. Both bio-oil samples obtained from untreated and treated biomass were composed of alcohols, ketones, aldehydes, phenols, alkenes, fatty acids, esters, aromatics, amino acids, nitrogen-containing heterocyclic compounds, and chlorinated/brominated compounds. The nitrogencontaining heterocyclic compounds, such as indole, could be generated from the decomposition of proteins. In addition, pyrazine derivatives were detected and their presence can be attributed to Maillard reactions, which are reaction of sugars and amines (Kruse et al., 2007). The bio-oil obtained from the demineralized biomass has a higher abundance and varieties of fatty acids, alcohols, and hydrocarbons. Oleic acid is the most abundant fatty acid. Only one fatty acid methyl ester was detected in the products, the hexadecanoic acid methyl ester. Different types of ketones and phenols were also identified in the bio-oils, but a higher diversity of phenols was found on the bio-oil obtained from the demineralized biomass. It could be attributed to a more efficient conversion of the polysaccharides and cellulose by reactions of hydrolysis, dehydration, cyclization among other reactions (Shuping et al., 2010; Li et al., 2012). A larger number of polycyclic aromatic compounds were identified in the untreated biomass; these compounds can be associated with an incomplete process.

Analysis of water soluble aqueous co-products. The aqueous fractions obtained with the treated biomass showed a weak acidity $(\mathrm{pH}=5.9)$ as expected for the demineralization process, while untreated biomass showed a weak basicity $(\mathrm{pH}=8.0)$. Table S2 in Supplementary Material list the compounds identified in the water soluble organics produced in HTL of the untreated and the demineralized biomass, respectively. Most of the compounds identified have low molecular weight and are polar. Organic acids such as butanoic, pentanoic, and hexadecanoic acid were detected. Glycerol, an important by product, was found in all the samples. Benzene derivatives and various nitrogen-containing compounds were also identified. In addition, some fatty acids were detected in the water phase suggesting the need for more effective extraction and separation of the different HTL products.

Analysis of gases. The gas fraction produced during the HTL was analyzed by gas chromatography coupled to a thermal conductivity detector for measuring relative $\mathrm{CO}_{2}$ and $\mathrm{CH}_{4}$ concentrations. We focus on these two gases because they are main component of the gas mixture. However, there are some research reports that inform the presence of small amounts of $\mathrm{C}_{2} \mathrm{H}_{4}, \mathrm{C}_{2} \mathrm{H}_{6}$, and $\mathrm{H}_{2} \mathrm{~S}$ when conditions similar to ours are used and in the presence of heterogeneous catalyst in the HTL process (Duan and Savage, 2010).

Carbon dioxide and methane generated from the different biomass feed stocks are presented in Table 4. The demineralized Sargassum biomass produced a higher amount of $\mathrm{CO}_{2}$ and $\mathrm{CH}_{4}$, than that of the untreated biomass. The detected percentages indicate that there are other components present in the product gases. The higher carbon dioxide content obtained for the demineralized biomass, suggest that the decarboxylation reactions were more productive, leading to obtain a higher bio-oil yield and quality.

\section{CONCLUSION}

The efficiency of five demineralization pretreatments (nanopure water, nitric acid, citric acid, sulfuric acid, and acetic acid) of 


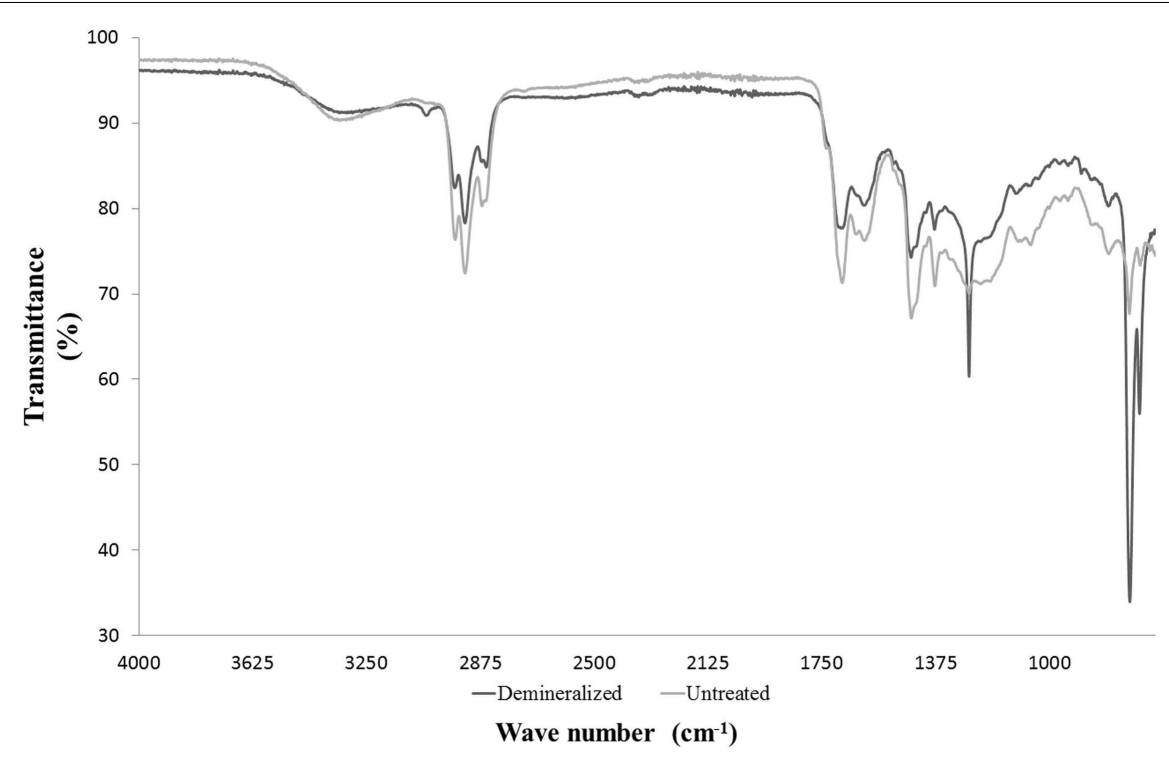

FIGURE 4 | Fourier transform infrared spectra of bio-oils obtained with Sargassum biomass. (a) Untreated and (b) demineralized with citric acid.

Table 4 | GC-TCD analysis of the HTL gas fraction obtained for untreated and demineralized Sargassum biomass.

\begin{tabular}{lcc}
\hline $\begin{array}{l}\text { Gas } \\
\text { fraction }\end{array}$ & $\begin{array}{l}\text { Sargassum } \\
\text { spp. (\%) }\end{array}$ & $\begin{array}{c}\text { Demineralized } \\
\text { Sargassum spp. (\%) }\end{array}$ \\
\hline $\mathrm{CH}_{4}$ & $0.25 \pm 0.01$ & $0.34 \pm 0.02$ \\
$\mathrm{CO}_{2}$ & $31 \pm 1$ & $41 \pm 1$
\end{tabular}

Sargassum spp. biomass and the effects of demineralization on HTL conversion were studied. It was found that all the demineralization pretreatments decreased the inorganic contents in the Sargassum biomass. However, citric acid was selected as the best option because it was able to remove almost all the mineral content (from 27.46 to $7 \%$ ash content) without significantly altering the organic composition and structure of biomass. In addition, it represents a more eco-friendly alternative. HTL process was performed on both demineralized and untreated Sargassum biomass. Results showed that demineralized biomass generated a higher bio-oil yield (22.2\%) when compared with the untreated biomass $(18.4 \%)$. The demineralization process did not significantly affect the HHV of the generated bio-oil, but since a higher bio-oil yield and a bio-char with high carbon content were obtained for the demineralized biomass, the net total ER in HTL was an increase from 47.4 to $63.5 \%$ when considering the energy associated with the bio-oil and the bio-char products. The chemical composition of the bio-oil obtained from the demineralized biomass confirms that the demineralization process facilitated the generation of a product richer in compounds with higher energy value such as alkanes and fatty acids. The bio-chars obtained from the HTL of the demineralized biomass had a higher percent of fixed carbon and HHV than the original feedstock therefore is suitable for further processing and ER.

\section{ACKNOWLEDGMENTS}

This project was supported by a grant from the US DoD Centers of Research Excellence in Science and Technology ARO Grant W911NF-11-1-0218 and the UPR Center for Renewable Energy and Sustainability. Authors are grateful to chemistry students Eduardo Roman, Ana P. Lozada, and Nelson Agosto from UPR-RP and the graduate students Will Costanzo, BSBchE, and Andrew Smola from UGA for their support with some of the analysis. We would like to thank the Material Characterization Center (MCC) at UPR, Rio Piedras Campus for SEM and EDS images.

\section{SUPPLEMENTARY MATERIAL}

The Supplementary Material for this article can be found online at http://www.frontiersin.org/Journal/10.3389/fenrg.2015.00006/ abstract

\section{REFERENCES}

Alvarez, R., Clemente, C., and Gómez-Limón, D. G. (2003). The influence of nitric acid oxidation of low rank coal and its impact on coal structure*. Fuel 82, 2007-2015. doi:10.1016/S0016-2361(03)00176-5

Anastasakis, K., and Ross, A. (2011). Hydrothermal liquefaction of the brown macroalga Laminaria saccharina: effect of reaction conditions on product distribution and composition. Bioresour. Technol. 102, 4876-4883. doi:10.1016/j.biortech. 2011.01.031

Azadi, P., Brownbridge, G., Mosbach, S., Smallbone, A., Bhave, A., Inderwildi, O., et al. (2014). The carbon footprint and non-renewable energy demand of algaederived biodiesel. Appl. Energy 113, 1632-1644. doi:10.1016/j.apenergy.2013.09. 027

Bach, Q.-V., Sillero, M. V., Tran, K.-Q., and Skjermo, J. (2014). Fast hydrothermal liquefaction of a Norwegian macro-alga: screening tests. Algal Res. 6(Pt B), 271-276. doi:10.1016/j.algal.2014.05.009

Bae, Y. J., Ryu, C., Jeon, J. K., Park, J., Suh, D. J., Suh, Y. W., et al. (2011). The characteristics of bio-oil produced from the pyrolysis of three marine macroalgae. Bioresour. Technol. 102, 3512-3520. doi:10.1016/j.biortech.2010.11.023

Bird, M. I., Wurster, C. M., de Paula Silva, P. H., Paul, N. A., and de Nys, R. (2012). Algal biochar: effects and applications. Glob. Change Biol. Bioenergy 4, 61-69. doi:10.1111/j.1757-1707.2011.01109.x 
Bligh, E. G., and Dyer, W. J. (1959). A rapid method of total lipid extraction and purification. Can. J. Biochem. Physiol. 37, 911-917. doi:10.1139/o59-099

Bridgwater, A., Meier, D., and Radlein, D. (1999). An overview of fast pyrolysis of biomass. Org. Geochem. 30, 1479-1493. doi:10.1016/j.biortech.2012.06.016

Brownbridge, G., Azadi, P., Smallbone, A., Bhave, A., Taylor, B., and Kraft, M. (2014). The future viability of algae-derived biodiesel under economic and technical uncertainties. Bioresour. Technol. 151, 166-173. doi:10.1016/j.biortech. 2013.10.062

Cheng, C.-H., Lehmann, J., Thies, J. E., Burton, S. D., and Engelhard, M. H. (2006). Oxidation of black carbon by biotic and abiotic processes. Org. Geochem. 37, 1477-1488. doi:10.1016/j.orggeochem.2006.06.022

Duan, P., and Savage, P. E. (2010). Hydrothermal liquefaction of a microalga with heterogeneous catalysts. Ind. Eng. Chem. Res. 50, 52-61. doi:10.1021/ie100758s

Elliott, D. C., Hart, T. R., Neuenschwander, G. G., Rotness, L. J., Roesijadi, G., Zacher, A. H., et al. (2013). Hydrothermal processing of macroalgal feedstocks in continuous-flow reactors. ACS Sustain. Chem. Eng. 2(2), 207-215. doi: $10.1021 / \mathrm{sc} 400251 \mathrm{p}$

Garland, C. W., Nibler, J. W., and Shoemaker, D. P. (2009). Experiments in Physical Chemistry. New York, NY: McGraw-Hill.

Guiry, M. D., and Blunden, G. (1991). Seaweed Resources in Europe: Uses and Potential. Chichester: John Wiley and Sons Ltd.

Guo, J., Zhuang, Y., Chen, L., Liu, J., Li, D., and Ye, N. (2012). Process optimization for microwave-assisted direct liquefaction of Sargassum polycystum C. Agardh using response surface methodology. Bioresour. Technol. 120, 19-25. doi:10.1016/j.biortech.2012.06.013

Hedge, J., and Hofreiter, B. (1962). Determination of reducing sugars and carbohydrates: anthrone colorimetric method. Methods Carbohydr. Chem. 1, 389-390.

Holdt, S. L., and Kraan, S. (2011). Bioactive compounds in seaweed: functional food applications and legislation. J. Appl. Phycol. 23, 543-597. doi:10.1007/s10811010-9632-5

Hu, Z., Zheng, Y., Yan, F., Xiao, B., and Liu, S. (2013). Bio-oil production through pyrolysis of blue-green algae blooms (BGAB): product distribution and bio-oil characterization. Energy 52, 119-125. doi:10.1016/j.energy.2013.01.059

Jena, U., and Das, K. (2011). Comparative evaluation of thermochemical liquefaction and pyrolysis for bio-oil production from microalgae. Energy Fuels 25, 5472-5482. doi:10.1021/ef201373m

Jena, U., Das, K., and Kastner, J. (2011). Effect of operating conditions of thermochemical liquefaction on biocrude production from Spirulina platensis. Bioresour. Technol. 102, 6221-6229. doi:10.1016/j.biortech.2011.02.057

Jiang, L., Hu, S., Sun, L. S., Su, S., Xu, K., He, L. M., et al. (2013). Influence of different demineralization treatments on physicochemical structure and thermal degradation of biomass. Bioresour. Technol. 146, 254-260. doi:10.1016/j.biortech.2013. 07.063

Jose, L. G.-E., Luke, B., Eduardo, M.-J., Upal, G., and Tom, S. (2013). “The potential of biochar amendments to remediate contaminated soils," in Biochar and Soil Biota, eds N. Ladygina and F. Rineau (Boca Raton, FL: CRC Press), 100-133.

Kruse, A., Maniam, P., and Spieler, F. (2007). Influence of proteins on the hydrothermal gasification and liquefaction of biomass. 2. Model compounds. Ind. Eng. Chem. Res. 46, 87-96. doi:10.1021/ie061047h

Landau, L. D., and Lifshitz, E. M. (1980). Course of Theoretical Physics. Moscow: Elsevier.

Li, D., Chen, L., Xu, D., Zhang, X., Ye, N., Chen, F., et al. (2012). Preparation and characteristics of bio-oil from the marine brown alga Sargassum patens. Bioresour. Technol. 104, 737-742. doi:10.1016/j.biortech.2011.11.011

Li, Y.-G., Xu, L., Huang, Y.-M., Wang, F., Guo, C., and Liu, C.-Z. (2011). Microalgal biodiesel in China: opportunities and challenges. Appl. Energy 88, 3432-3437. doi:10.1016/j.apenergy.2010.12.067

Liu, X., and Bi, X. T. (2011). Removal of inorganic constituents from pine barks and switchgrass. Fuel Process. Technol. 92, 1273-1279. doi:10.1016/j.fuproc.2011. 01.016

López Barreiro, D., Prins, W., Ronsse, F., and Brilman, W. (2013). Hydrothermal liquefaction (HTL) of microalgae for biofuel production: state of the art review and future prospects. Biomass Bioenergy 53, 113-127. doi:10.1016/j.biombioe. 2012.12.029

Mayer, Z. A., Apfelbacher, A., and Hornung, A. (2012). Effect of sample preparation on the thermal degradation of metal-added biomass. J. Anal. Appl. Pyrolysis 94, 170-176. doi:10.1016/j.jaap.2011.12.008
Nautiyal, P., Subramanian, K., and Dastidar, M. (2014). Production and characterization of biodiesel from algae. Fuel Process. Technol. 120, 79-88. doi:10.1016/j. fuproc.2013.12.003

Neveux, N., Yuen, A. K., Jazrawi, C., Magnusson, M., Haynes, B. S., Masters, A. F. et al. (2014). Biocrude yield and productivity from the hydrothermal liquefaction of marine and freshwater green macroalgae. Bioresour. Technol. 155, 334-341. doi:10.1016/j.biortech.2013.12.083

Patwardhan, P. R., Satrio, J. A., Brown, R. C., and Shanks, B. H. (2010). Influence of inorganic salts on the primary pyrolysis products of cellulose. Bioresour. Technol. 101, 4646-4655. doi:10.1016/j.biortech.2010.01.112

Peterson, A. A., Vogel, F., Lachance, R. P., Fröling, M., Antal, M. J. Jr., and Tester, J. W. (2008). Thermochemical biofuel production in hydrothermal media: a review of sub-and supercritical water technologies. Energy Environ. Sci. 1, 32-65. doi:10.1039/b810100k

Qu, Y., Wei, X., and Zhong, C. (2003). Experimental study on the direct liquefaction of Cunninghamia lanceolata in water. Energy 28, 597-606. doi:10.1016/S03605442(02)00178-0

Ross, A., Anastasakis, K., Kubacki, M., and Jones, J. (2009). Investigation of the pyrolysis behaviour of brown algae before and after pre-treatment using PY-GC/MS and TGA. J. Anal. Appl. Pyrolysis 85, 3-10. doi:10.1016/j.jaap.2008. 11.004

Ross, A. B., Jones, J. M., Kubacki, M. L., and Bridgeman, T. (2008). Classification of macroalgae as fuel and its thermochemical behaviour. Bioresour. Technol. 99, 6494-6504. doi:10.1016/j.biortech.2007.11.036

Rowbotham, J. S., Dyer, P. W., Greenwell, H. C., Selby, D., and Theodorou, M. K. (2013). Copper (II)-mediated thermolysis of alginates: a model kinetic study on the influence of metal ions in the thermochemical processing of macroalgae. Interface Focus 3, 20120046. doi:10.1098/rsfs.2012.0046

Shakirullah, M., Ahmad, I., Rehman, H., Ishaq, M., Khan, U., and Ullah, H. (2006). Effective chemical leaching and ash depletion of low rank coal with EDTA and citric acid. J. Chem. Soc. Pak. 28(1), 56.

Shuping, Z., Yulong, W., Mingde, Y., Kaleem, I., Chun, L., and Tong, J. (2010). Production and characterization of bio-oil from hydrothermal liquefaction of microalgae Dunaliella tertiolecta cake. Energy 35, 5406-5411. doi:10.1016/j.energy.2010. 07.013

Singh, R., Bhaskar, T., and Balagurumurthy, B. (2015). Effect of solvent on the hydrothermal liquefaction of macro algae Ulva fasciata. Process Saf. Environ. Prot. 93, 154-160. doi:10.1016/j.psep.2014.03.002

Toor, S. S., Rosendahl, L., and Rudolf, A. (2011). Hydrothermal liquefaction of biomass: a review of subcritical water technologies. Energy 36, 2328-2342. doi:10.1016/j.energy.2011.03.013

Venteris, E. R., Skaggs, R. L., Wigmosta, M. S., and Coleman, A. M. (2014). A national-scale comparison of resource and nutrient demands for algae-based biofuel production by lipid extraction and hydrothermal liquefaction. Biomass Bioenergy 64, 276-290. doi:10.1016/j.biombioe.2014.02.001

Ververis, C., Georghiou, K., Danielidis, D., Hatzinikolaou, D. G., Santas, P., Santas, R., et al. (2007). Cellulose, hemicelluloses, lignin and ash content of some organic materials and their suitability for use as paper pulp supplements. Bioresour. Technol. 98, 296-301. doi:10.1016/j.biortech.2006.01.007

Villadsen, S. R., Dithmer, L., Forsberg, R., Becker, J., Rudolf, A., Iversen, S. B., et al. (2012). Development and application of chemical analysis methods for investigation of bio-oils and aqueous phase from hydrothermal liquefaction of biomass. Energy Fuels 26, 6988-6998. doi:10.1021/ef300954e

Wiechelman, K. J., Braun, R. D., and Fitzpatrick, J. D. (1988). Investigation of the bicinchoninic acid protein assay: identification of the groups responsible for color formation. Anal. Biochem. 175, 231-237. doi:10.1016/0003-2697(88) 90383-1

Zhou, D., Zhang, L., Zhang, S., Fu, H., and Chen, J. (2010). Hydrothermal liquefaction of macroalgae Enteromorpha prolifera to bio-oil. Energy Fuels 24, 4054-4061. doi:10.1021/ef100151h

Zhuang, Y., Guo, J., Chen, L., Li, D., Liu, J., and Ye, N. (2012). Microwave-assisted direct liquefaction of Ulva prolifera for bio-oil production by acid catalysis. Bioresour. Technol. 116, 133-139. doi:10.1016/j.biortech.2012.04.036

Conflict of Interest Statement: The authors declare that the research was conducted in the absence of any commercial or financial relationships that could be construed as a potential conflict of interest. The Guest Associate Editor S. Kent Hoekman 
declares that, despite being affiliated to the same institution as author Umakanta Jena, the review process was handled objectively and no conflict of interest exists.

Received: 18 September 2014; accepted: 26 January 2015; published online: 11 February 2015.

Citation: Díaz-Vázquez LM, Rojas-Pérez A, Fuentes-Caraballo M, Robles IV, Jena $U$ and Das KC (2015) Demineralization of Sargassum spp. macroalgae biomass: selective hydrothermal liquefaction process for bio-oil production. Front. Energy Res. 3:6. doi: 10.3389/fenrg.2015.00006
This article was submitted to Bioenergy and Biofuels, a section of the journal Frontiers in Energy Research.

Copyright (c) 2015 Díaz-Vázquez, Rojas-Pérez, Fuentes-Caraballo, Robles, Jena and Das. This is an open-access article distributed under the terms of the Creative Commons Attribution License (CC BY). The use, distribution or reproduction in other forums is permitted, provided the original author(s) or licensor are credited and that the original publication in this journal is cited, in accordance with accepted academic practice. No use, distribution or reproduction is permitted which does not comply with these terms. 